Канд. техн. наук Г.С. Бауліна

Cand. of techn. sciences G.S. Baulina

\title{
ФОРМУВАННЯ МОДЕЛІ ФУНКЦІОНУВАННЯ ТРАНСПОРТНО-ЛОГІСТИЧНОГО ЦЕНТРУ
}

\section{THE MODEL CREATION OF FUNCTIONING THE TRANSPORT AND LOGISTICS CENTRE}

\author{
Представив д-р техн. наук, професор А.М. Котенко
}

Вступ. Сучасний стан залізничної галузі вимагає формування транспортнологістичної інфраструктури. Ї̈̈ головними елементами $\epsilon$ транспортно-логістичні центри (ТЛЦ), які останнім часом активно створюються та розвиваються. Використовуючи наявну інфраструктуру, ТЛЦ значно підвищують якість послуг та сукупний обіг вантажоперевезень за рахунок залучення додаткової клієнтури.

Постановка проблеми. Створення транспортно-логістичних центрів дозволяє вирішити проблему доставки вантажів від постачальника до споживача в найкоротші терміни i 3 найменшими фінансовими витратами. У зв'язку з цим для того, щоб оптимально використовувати свої складські, інформаційні, технічні та людські ресурси, необхідний постійний моніторинг та планування роботи ТЛЦ. У результаті при прийнятті якісних рішень, які визначають структуру та стратегію роботи транспортно-логістичного центру, виникає необхідність у формуванні гнучкої оптимізаційної моделі.

Аналіз останніх досліджень i публікацій. Дослідженням роботи логістичних центрів та ефективності їх роботи останнім часом приділяється чимало уваги. У роботі [1] розглянуто систему оцінки ефективності функціонування транспортно-логістичного центру та запропоновано комплексний показник для оцінки його ефективності. У 
дослідженнях [2] сформовано модель оптимізації логістики контейнерних перевезень 3 урахуванням витрат при складуванні на контейнерному терміналі на основі статистичних методів розрахунку. Теоретико-методологічні основи підвищення ефективності роботи транспортно-логістичної системи 3 мінливою структурою, що взаємодіє із зовнішнім середовищем, розглянуто у роботі [3]. Сутність досліджень [4] полягає у вирішенні задачі оптимального розміщення у вузлі транспортного логістичного центру та вибору його основних параметрів. $\mathrm{y}$ роботі [5] запропоновано структуру логістичного управління, що включає диспетчерські, ситуаційні та інформаційно-аналітичні центри управління з урахуванням взаємодії різних типів потоку та різних видів транспорту.

Отже, в зазначених дослідженнях питання оптимізації роботи транспортнологістичного центру не отримало достатнього висвітлення.

Формулювання мети (постановка завдання). Метою наукової роботи $\epsilon$ вирішення задачі формування оптимізаційної моделі функціонування транспортно-логістичного центру, що враховує багатопараметричність, багатокритеріальність та невизначеність вихідної інформації. У моделі необхідно враховувати нестаціонарність перебігу виробничих процесів, що обумовлено факторами зовнішнього середовища, a також імовірнісну природу [6,7]. Серед цих факторів можна виділити нерівномірність надходження транспортних засобів та вантажів, змінення вимог вантажовласників, пов'язаних 3 наданням послуг, відмови в роботі навантажувальнорозвантажувальної техніки.

Викладення основного матеріалу. Транспортно-логістичний центр належить до класу складних динамічних систем, компоненти яких мають між собою стохастичні функціональні зв'язки. Ці зв'язки слабо структуровані і їх формалізація складає значні труднощі.

Методи оптимізації транспортнологістичного центру мають враховувати основне призначення логістики досягнення синергетичного ефекту у підвищенні якості організації обслуговування замовлень при оптимальному використанні всіх видів ресурсів ТЛЦ. Отже, задача оптимізації роботи ТЛЦ $є$ багатокритеріальною, а вибір критеріїв оптимізації та умов обмежень для кожного центру може бути унікальним. Але ряд критеріїв оптимальності можна використовувати у моделі будь-якого логістичного центру.

Цільова функція моделі функціонування ТЛЦ має такий вигляд:

$$
R(t)=F[N(t), P(t), V(t), H(t)]
$$

де $N(t)$ - вектор параметрів, що відображає вхідний потік замовлень;

$P(t)$ - вектор параметрів, що характеризують структуру та оснащеність ТЛЦ;

$V(t)$ - вектор параметрів, що відображає графік роботи ТЛЦ та організацію обробки замовлень;

$H(t) \quad$ - вектор параметрів, що характеризують обсяг послуг, які пропонуються ТЛЦ своїм клієнтам.

Вектор вхідного потоку містить такі параметри:

$$
N(t)=\left[N_{\kappa l}(t), N_{3}(t), N_{o \sigma}^{\max }(t), N_{B}^{\max }(t)\right],
$$

де $N_{\kappa л}(t)$ - кількість клієнтів;

$N_{3}(t)$ - кількість замовлень в одиницю часу;

$N_{\text {об }}^{\max }(t) \quad-\quad$ максимальний обсяг замовлення;

$N_{s}^{\max }(t)$ - максимальна вага замовлення.

Даний вектор параметрів необхідно буде змінювати в процесі оптимізації 
моделі, для оцінки реакції ТЛЦ на змінення параметрів вхідного потоку.

Вектор параметрів, що характеризують структуру та оснащеність транспортно-логістичного центру,

$$
P(t)=\left\lfloor P_{\text {ски }}(t), P_{n}(t), P_{\text {nерс }}(t), P_{\text {мех }}(t)\right\rfloor,
$$

де $P_{c к л}(t)$ - вид складування;

$P_{n}(t) \quad-$ кількість та продуктивність пунктів навантаження та вивантаження;

$P_{\text {nерс }}(t)$ - кількість та продуктивність персоналу, зайнятого у різних відділах центру;

$P_{\text {мех }}(t) \quad$ - кількість та продуктивність засобів механізації.

Вектор структури ТЛЦ та організації обробки замовлень

$$
V(t)=\left[V_{n}(t), V_{\text {мех }}(t), V_{n p}(t), V_{\text {вив }}^{\text {зб }}(t), V_{\text {зб }}^{\text {нав }}(t)\right],
$$

де $V_{n}(t)$ - час роботи пунктів навантаження, розвантаження;

$V_{\text {мех }}(t)$ - час роботи засобів механізації;

$V_{n p}(t)$ - час роботи працівників ТЛЦ;

$V_{\text {вив }}^{36}(t)$ - шлях просування вантажу від місця вивантаження до місця зберігання;

$V_{3 б}^{\text {нав }}(t)$ - шлях просування вантажу від місця зберігання до місця навантаження.

Даний вектор параметрів є основним механізмом оптимізації процесу функціонування ТЛЦ.

Вектор параметрів, що характеризують обсяг послуг, які пропонуються ТЛЦ своїм клієнтам,

$$
H(t)=\left[H_{в}(t), H_{m}(t), H_{\text {обл }}(t)\right],
$$

де $H_{\theta}(t)$ - види послуг, що пропонує ТЛЦ;

$H_{m}(t)$ - тарифи на послуги ТЛЦ;

$H_{\text {обл }}(t)$ - необхідне обладнання для реалізації всього комплексу послуг.
Як обмеження моделі можна розглядати функціональні ресурси ТЛЦ, потреби замовників та інше.

Після визначення параметрів цільової функції логістичного центру необхідно встановити критерії оцінки ефективності його роботи. Ефективність роботи ТЛЦ можна оцінити відповідно до таких ключових критеріїв, як: обсяг наданих послуг, дохід від обробки замовлення, витрати на обробку замовлення і тривалість обробки замовлення.

Критерії можна подати у такому вигляді:

$$
\left\{\begin{array}{l}
H(t) \rightarrow o p t \\
\sum_{i}^{r} D_{i} \rightarrow \max \\
\sum_{i}^{r} C_{i} \rightarrow \min \\
\sum_{i}^{r} T_{i} \rightarrow \min
\end{array}\right.
$$

при обмеженнях

$$
\left\{\begin{array}{l}
\sum_{i}^{r} C_{i} \leq 3_{i}, i=1 \ldots m \\
T_{i} \leq T_{u}
\end{array},\right.
$$

де $r$ - кількість замовлень;

$D_{i}$ - дохід від обробки і-го замовлення;

$C_{i} \quad-\quad$ витрати на обробку і-го замовлення;

$T_{i}$ - тривалість обробки і-го замовлення;

$3_{i}$ - сумарні кошти, виділені на обробку i-го замовлення;

$T_{н} \quad-$ нормативний час на обробку замовлення.

Обсяг наданих послуг $є$ якісним показником. Будемо вважати, що цей обсяг $\epsilon$ незмінною й оптимальною для ТЛЦ і його клієнтів величиною.

Дохід від обробки замовлення 


$$
D=D_{с к л}+D_{\text {зб }}+D_{n л}+D_{\text {дод }}
$$

де $D_{\text {скл }}$ - дохід від складування вантажу;

$D_{\text {зб }}$ - дохід від зберігання вантажу;

$D_{n л}-$ дохід від планування доставки вантажу;

$D_{\text {до }}$ - дохід від додаткових послуг ТЛЦ. Витрати на обробку замовлення

$$
C=C_{\text {скл }}+C_{\text {транс }}+C_{\text {зб }}+C_{n л}+C_{\text {як.в }}+C_{\text {дод }},
$$

де $C_{c к r}$ - витрати на складування вантажу;

$C_{\text {mранс }}-$ витрати на транспортування вантажу у складі ТЛЦ;

$C_{\text {зб }}$ - витрати на зберігання вантажу;

$C_{n л}$ - витрати на планування доставки;

$C_{\text {як.в }}$ - витрати, пов'язані 3 якістю сервісу (повернення вантажу);

$C_{\text {дод }}$ - витрати на додаткові послуги.

Мінімізація витрат на обробку замовлення $\epsilon$ одним 3 найважливіших критеріїв оптимізації роботи ТЛЦ.

Тривалість обробки і-го замовлення $\epsilon$ також однією 3 вагомих величин, що визначає узгодженість роботи ТЛЦ всередині логістичної системи. В ідеальному випадку ТЛЦ повинен виконувати замовлення точно в строк, який визначає вантажовідправник.

Аналіз роботи ТЛЦ показує, що логістичні центри являють собою складні об'єкти управління, які характеризуються великою кількістю технологічних зв'язків між окремими технологічними зонами. Складність технології ТЛЦ, випадковий характер вхідних потоків вантажів і транспорту, велика кількість обмежень та факторів, що обумовлені технологічним регламентом та визначають ефективність роботи об'єкта управління, а також наявність чисельних залежностей між цими факторами викликають значні труднощі при формуванні оптимізаційної моделі функціонування транспортно-логістичного центру. Крім цього, розмірність та складність збільшуються у випадку оцінки ефективності роботи ТЛЦ в умовах множини критеріїв, що характеризують якість його роботи.

Висновки. Отже, при формуванні оптимізаційної моделі роботи транспортнологістичного центру найбільш ефективним слід вважати багаторівневий системний підхід, при якому задача подається у вигляді ієрархічної системи більш простих підзадач, вирішення яких адекватно вирішенню загальної задачі.

\section{Сиисок літератури}

1. Науменко, М.А. Система оценки эффективности функционирования транспортнологистического центра [Текст] / М.А. Науменко, Т.В. Коновалова // Транспорт: наука, техника, управление. - 2012. - № 3. - С. 62-65.

2. Забелин, М.А. Математическая модель оптимизации логистики контейнерных перевозок на железнодорожном транспорте [Текст] / М.А. Забелин // Транспорт: наука, техника, управление. - М.: ВИНИТИ, 2009. - № 3. - С. 14-18.

3. Корчагин, В.А. Математическая модель управления грузовыми транспортнологистическими системами с переменной структурой [Текст] / В.А. Корчагин, С.А. Ляпин, Ю.Н. Ризаева, Е. А. Лебедев // Транспорт: наука, техника, управление. - 2012. - № 3. - С. 3032.

4. Резер, С.М. Математическое моделирование логистической системы управления перевозками [Текст] / С.М. Резер, Т.Т. Куанышева // Транспорт: наука, техника, управление. - М.: ВИНИТИ, 2008. - № 8. - С. 14-18. 
5. Куренков, П.В. Логистизация управления грузовыми перевозками при взаимодействии различных типов потоков и различных видов транспорта [Текст] / П.В. Куренков, В.П. Мохонько, Ю.А. Полянский // Системная логистика и центр консолидации грузопотоков на международных трассах: труды II Междунар. науч.-практ. конф. - Самара, 2003. - Вып. 1. - С. 32-56.

6. Гилл, Ф. Практическая оптимизация [Текст] / Ф. Гилл, У. Мюррей, М. Райт. - М.: Мир, 1985. - 509 с.

7. Карманов, В. Г. Математическое программирование [Текст]: учеб. пособие / В.Г. Карманов. - М.: ФИЗМАТЛИТ, 2004. - 264 с.

Ключові слова: транспортно-логістичний центр, оптимізаційна модель, багатопараметричність, багатокритеріальність.

\section{Анотації}

У роботі розглянуто формування моделі транспортно-логістичного центру, що враховує багатопараметричність та невизначеність вхідної інформації. Визначено критерії оцінки ефективності роботи транспортно-логістичного центру.

В работе рассмотрено формирование модели транспортно-логистического центра, которая учитывает многопараметричность и неопределенность исходной информации. Определены критерии оценки эффективности работы транспортно-логистического центра.

In this work we consider the creation of model the transport and logistics center, which takes into account a lot of parametrics and indeterminacy of source information. The criteria for evaluation of work efficiency of transport and logistics center are identified. 